\title{
Philosophy and teacher education in England - the long view
}

John White

UCL Institute of Education

\begin{abstract}
Until recently teacher education in England has always contained a 'philosophical' element - to do with what education is for in the light of human nature. The paper traces its history since 1839, through inspirational approaches - based first on religion and later on psychology - to the critical approach of R S Peters and his colleagues in the 1960s. It then looks at the existential crisis faced by this kind of philosophy of education after changes in education policy in the 1980s; and at ways it has found of overcoming it - at the expense, however, of partially turning away from its earlier raison d'être in teacher education. The paper concludes with a discussion of what would be needed for it to resume its old role.
\end{abstract}

Teacher education in England dates back to 1839 and the beginnings of a national system of education. ${ }^{1}$ It has always included specific guidance about how to teach, keep order, motivate children. But as well as mastering the details of their craft, teachers have always needed some understanding of what it is and what its aims are. Trainee bricklayers need plenty of experience of specifics, too, but the purposes of laying bricks are reasonably obvious. Teaching is different. Why children need to learn things and what areas of learning are most important are controversial questions: they take one immediately into priorities among personal, moral, civic and economic aims and into the good life for human beings in general. Teachers also need a good grasp of the 'material' with which they have to work: human minds are less easy to fathom than bricks.

For nearly all its 180 years an important component of English teacher education dealt with the nature of education and its aims in the light of the kind of creatures human beings are. There has been a rough division between the practical and the philosophical aspects of teacher education, using 'philosophical' here in a very wide sense, not confined to the academic discipline of philosophy.

This dual pattern has not obtained throughout the whole period. It covers only its first 150 years. Since the 1980 s, while teachers have had a good grounding in practical details, there has been far less emphasis on more general, 'philosophical', issues. I come back to this later.

The nineteenth century 
A guide to the 'philosophical' part of teacher training between 1839 and 1944 is Ashley Berner's D Phil thesis 'Metaphysics in Educational Theory: educational philosophy and teacher training in England (1839-1944)' (Berner 2008). Her central theme is the dramatic change that occurred over this century in the kind of 'philosophy' students were taught. The religious framework that dominated the first half of this period gave way to a scientific one based on the new discipline of psychology.

Berner illustrates this by comparing ideas in two best-selling textbooks, one from each end of her historical span. The first, used in nineteenth-century training colleges, is John Gill's Introductory Text Book to School Education, Method, and School Management, first published in 1857 and selling 50,000 copies between 1857 and 1882 (Berner 2008: 6). This 'employed religious justifications for education and Biblical understandings of the human person' (p.3). Gill saw the child as a fallen being, 'a temple in ruins, which it is the aim of education to remodel in all its pristine beauty' (p.7). Nurturing the moral intelligence is 'the highest aim of the teacher'. 'As its special work, [the school] has to furnish those instruments of culture, that intellectual discipline, and those habits of strenuous labour, necessary to the pupil's advancement in intelligence, which will open to him higher sources of enjoyment than such as are merely animal and which will fit him for a faithful and intelligent discharge of the duties which will await him in the future' (p.7).

\section{The early twentieth century}

The second book is Percy Nunn's Education: Its Data and First Principles (1920), reprinted 24 times by 1947. 'For some 40 years Nunn's Education served as a 'bible' for educational professionals and public alike' (Aldrich 2002: 65). Nunn rejected universal aims for education such as the 'formation of character' or 'preparation for complete living'. This is because 'there are as many ideals as there are persons. Educational efforts must... be limited to securing for everyone the conditions under which Individuality is most completely developed' (Berner p.9, Nunn p.13). Discovering that individuality in every child is the task of scientific psychology, informed by the theory of evolution. Education, based on a study of the growth of children's instincts and appetites, enables each child to engage in a process of self-creation or self-expression.

A further change between the two periods is that the centre of gravity in 'philosophising' about education shifted from the - usually religiously-based - training colleges to newly created university departments of education. The most influential of these from its foundation in 1902 was what became the University of London Institute of Education (ULIE) and is now UCL Institute of Education. It was here that Nunn taught and later became Principal. As Berner points out, it was here that he cooperated with colleagues like Susan Isaacs to create a new education built around children's natural development. Until 1975 the Institute was also at the administrative and teaching hub of a network of training colleges in and around London. This helped it to disseminate into the training college world more generally the science-based approach with which it became associated in the 1902 to 1944 period and beyond.

By the end of the second world war, then, for over a century the English school system had been guided by two sorts of 'philosophy', one religious, the other (said to be) scientific. I write 'said to be' for a reason. If we examine Nunn's thought a little more closely, we see 
that it goes beyond science - understood as an empirical discipline - and moves in a religious direction. To take one of many possible examples, in elaborating his notion of individuality he writes

Our ultimate duty is not to let our nature grow untended and disorderly, but to use our creative energies to produce the most shapely individuality we can attain. For only in that way can we be, as we are bound to be, fellow-workers with the Divine in the universe. (p.249)

Although Nunn was influenced by evolution theory, it is clear from this and other passages that he held a teleological view of the topic, seeing the evolution of species, whose highest manifestation is the individuality of human beings, as the working out of God's purposes. In this way he continued rather than broke with the religious picture of human life and its moral obligations that had guided teacher education since the 1830 s.

A related point about Nunn's approach is that as an empirical discipline psychological science has nothing to say about how things ought to be. In his reference to 'our ultimate duty' in the passage just quoted, we see an example of how he transgressed this. His claim that there are no 'universal aims' of education - like the formation of character, for instance - looks as if he is stepping aside from the moral prescriptiveness so much a feature of religious-based education. But in going on to state that education is properly about the development of individuality, he is not only describing a universal aim but also recommending it (White 1982: 7-8).

\section{The late twentieth century}

The idea that teacher education should contain a 'philosophical' as well as a 'practical' element continued to flourish in post-war England: as in the period that Berner studied, teachers were felt to need guidance about the aims of education and related topics like the nature of human beings. Likewise, the University of London Institute of Education (ULIE) remained, at least initially, the main source whereby 'philosophical perspectives' were transmitted more widely, to other teacher-training institutions and more widely still to the world of teachers and policy-makers.

From the 1960s teacher education at the Institute of Education became celebrated for a new kind of educational theorising that circumvented - or at least was intended to circumvent - the problem of blurring the line between empirical fact and ethical values. Different educational disciplines were to work together on different kinds of issue. Value questions, eg about educational purposes, became the province of the academic discipline of philosophy of education (no inverted commas as in the broader sense of 'philosophy' used so far in this paper). So did conceptual investigations about the nature of knowledge and the sort of creatures human beings are. Sociology, psychology and history of education as well as comparative education studied their own specialised empirical topics. Interdisciplinary cooperation was encouraged - teaching about punishment, for instance, from ethical, sociological and psychological perspectives. 
The academic discipline called philosophy of education now covered what I have previously called the 'philosophical' element in teacher education. ${ }^{2}$ The 1960 s changes enabled the Institute to preserve its earlier aim of helping teachers and policy-makers across the country to acquire a broad understanding of the nature of education. But there was an important difference between the two periods. Nunn's and his colleagues' approach - like the religious ideas that preceded it - had promulgated an ex cathedra vision of a desirable education, designed to inspire teachers with an exalted appreciation of their calling. But critical reflection was at the heart of 1960s and post-1960s philosophy of education. The differing views of R S Peters, P H Hirst, R F Dearden and others who wrote on the nature of education, the curriculum, knowledge and the human mind were subjected to careful appraisal. So were the assumptions embedded in official reports like the Plowden Report of 1967 (Peters 1969).

Unlike the inspirational kind of 'philosophising' that preceded it, this new approach owed the rigour with which it tackled educational issues to its close links with academic philosophy. Peters himself came to the Institute in 1962 from teaching the subject at Birkbeck College, University of London, where his colleagues D W Hamlyn and R K Elliott both became celebrated contributors to the new philosophy of education. - As did other major figures in British philosophy like M Oakeshott, G Ryle, R M Hare, A Quinton, M Hollis and M Warnock.

Work in this new field took place not only in classes at the Institute and at other universities and colleges of education, but also at local and national meetings of the newly formed Philosophy of Education Society of Great Britain (PESGB), founded in 1965, and in the pages of its journal The Journal of Philosophy of Education (JOPE), founded (under an earlier title) the following year. Through the frequent continuing debates and disagreements in all these locations, teachers and policy-makers who studied the ideas of Peters and others were encouraged to work out their own autonomous positions. The inspirational words of an eminent authority were no longer what were thought to be needed. They were indeed often put to the test. ${ }^{3}$

The 1960s and 1970s saw teacher education transformed. Teaching became an all-graduate profession. Pre-service teacher education covered both the one-year Postgraduate Certificate in Education (PGCE) and the newly introduced three- or four-year Bachelor of Education (BEd) courses. This was a time of massive change in the secondary school system as comprehensive schools replaced separate grammar and secondary modern schools. Government and local education authorities threw their weight behind an intellectual upgrading of the teaching force. All branches of educational theory, philosophy of education included, were prominently represented in PGCE and BEd courses across the country. There was also a big expansion in in-service courses at Diploma, MA and doctoral level. In the mid1960s, too, the British government directly backed a full-time course to be taught at the Institute of Education. It was called the Diploma in Philosophy of Education and designed to prepare lecturers to teach the subject in colleges of education.

The new approach had imperfections. Most of those studying philosophy of education in London and across the country were student teachers and understandably too preoccupied by more practical concerns to give much attention to the substantial programme of lectures 
and seminars in the subject arranged for them. This was especially true of intending teachers on the one-year PGCE course as they had much less time than those doing a BEd. Critical reflection was sometimes less in evidence than reproducing what a teacher or textbook said. At faculty level, cooperative interaction with empirical disciplines of education was often neglected in the pursuit of building up new academic empires. ${ }^{4}$

Yet many in the field saw these as obstacles to be overcome. They cleaved as firmly as the followers of John Gill and Percy Nunn to the view that teachers cannot live by nuts-andbolts alone. At the Institute of Education in the 1970s philosophers helped to spearhead a slimming down of the educational theory part of the PGCE. Philosophical issues were incorporated into interdisciplinary, practice-orientated seminars on such things as the aims of education, teaching and learning, justice and equality, classroom discipline. ${ }^{5}$

It became plainer, too, that in-service rather than pre-service work with teachers was likely to have most impact on the profession. Teachers trained to reflect on the larger bearings of their work were better able to do so teething troubles behind them. Schools were at that time wholly responsible for their curricula. It made good sense for every school to see that some staff, not least senior staff, were equipped to look critically at wider issues. With this in mind, from the 1960s onwards Diploma and MA in-service courses at the Institute of Education and elsewhere offered teachers a good grounding in areas of general philosophy like ethics, epistemology, philosophy of mind, aesthetics and political philosophy, as well as considering their application to educational issues. ${ }^{6}$ Philosophers at the Institute also ran tailor-made 'Broader Perspectives' courses for London head teachers. ${ }^{7}$

The Easter School in Philosophy was also for serving teachers. This was an annual week-long residential course in philosophy organised and taught by Institute of Education staff. Its ran throughout most of the 1960s and the 1970s. 'Teachers would spend a week during the Easter school holiday in a College of Education in the London area, Kent or Sussex listening to and discussing lectures by two well-known philosophers. Over the years these included Bernard Williams, Anthony Quinton, Peter Winch, Ninian Smart, David Hamlyn. The day began with informal discussions over breakfast, lectures and seminars followed and, with a brief break in the afternoon, it finished around 10pm. At one of these Easter schools Robert Dearden, then a primary school teacher studying for an external London philosophy degree, was talent-spotted by Richard Peters. He was subsequently appointed to the Institute of Education' (Davis and White 2017).

Post-1960 philosophy of education also had an influence on national policy-making, from the critique of the Plowden Report mentioned above, to first thoughts about a national curriculum, and to the impact on the inspectorate (HMI) of Hirst's work on the curriculum.

In the early 1980s the future looked bright.

\section{Into the new millennium}

But it proved a mirage. The late 1980s saw nationwide decimation of in-service courses on education - including those in philosophy of education - as teachers now had to fund themselves rather than being fully financially supported by the state from an earmarked 
'pool'. ${ }^{8}$ This was part of a more general onslaught in the Thatcher years on the place of educational studies in teacher education. Publications on this from right-wing think tanks like the Hillgate Group and from the philosopher Anthony O'Hear (1988: 26) were directed mainly to initial training (ITE). They may have helped to diminish even further what little philosophy of education there was in ITE at the Institute and elsewhere.

A further disadvantage facing philosophy of education, especially its in-service provision, was that the arrival of the National Curriculum in 1988 meant schools no longer had carte blanche over their aims and curricula. There was therefore less incentive for teachers to think through what they were doing from fundamentals. In the three decades since then, accountability pressures have turned teachers inwards towards the specifics of improving their own and their school's performance as measured by national and international standards. In initial teacher education, the increased ratio of school experience to university-based studies has left even less room in the PGCE and other ITE courses for attention to broader horizons.

These new directions at first threatened the very existence of philosophy of education. The subject was still being taught, although everywhere courses and staffing began to suffer erosion. In the 1990s the threat was averted by a shift, encouraged by research assessment exercises in universities, away from teacher education and into publication, especially of articles in international as well as British journals. The growth of the internet around the same time aided international links and helped to remodel philosophy of education as a global enterprise.

The internationalisation of the subject has not been wholly new: from the 1960s there had been strong links between British philosophy of education and scholars from Commonwealth countries and the USA. But that was at a time when servicing teacher education was still the subject's main mission. In 2017, it no longer is. This is partly a consequence of internationalisation, as national education systems and arrangements for teacher education vary from one jurisdiction to another. This has meant that a philosophical critique, say, of curriculum reforms in England might well be of little interest to colleagues in the USA, Poland or Japan, and vice-versa.

In the new world of research assessment exercises and their pressure on academics to publish as much as they can, it is not surprising that philosophy of education has become more of a bookish enterprise. Its focus since the 1990s has been shifting away from the world of schools and teacher education towards matters of specialist interest among university scholars. Much of this scholarship has taken the form of discussion of a particular philosopher's views where these are in some way relevant to education. In the early years of JOPE, there were few articles of this sort - only two in its first decade, on Rousseau and Sartre. Virtually every paper looked at educational topics directly, not through the lens of a celebrated philosopher. This meant that a reader or replier wasn't hampered by not knowing enough about Sartre or whoever: everybody could contribute to the debate. In recent years, there have been many more articles in JOPE and comparable journals only fully accessible if you are familiar with a certain writer. Since this has meant more activity among specialised groups, there is now less room for anyone to join in a debate. In the first two 2017 issues of JOPE, for instance, there were articles centring on Ranciere, Carlyle and 
Foucault, Adorno, Kant, Habermas, Arendt, Levinas (2), Nietzsche (2), Dewey (2), Cora Diamond, the Nyāya School of classical Indian philosophy, Heidegger (2), Merleau-Ponty (2), Agamben, Wittgenstein, Augustine and Confucius.

On a somewhat larger canvas, in 2012 19\% of JOPE articles mentioned in their title one or occasionally two specific philosophers; in subsequent years 37\%, 49\%, 47\% and in 2016 $49 \%$. Nearly half the journal's content is now, therefore, of this kind. This compares with $2 \%$ for the 1967-76 decade. Taking the period 2012-16 together, 15\% of all articles were about European philosophers of the late twentieth century and later.

The shift does not mean that the critical reflection stressed in 1960s philosophy of education is no longer present. The difference is that, in papers like those just indicated, it is applied more to the ideas of individual thinkers and less to issues pertinent to teacher education and the actual world of education.

Does the greater emphasis in recent issues of JOPE on individual philosophers, not least recent European philosophers, reflect a similar change in general philosophy? Articles in the main philosophical journals remain overwhelmingly problem-centred. ${ }^{9}$ On the other hand, many articles on particular thinkers are published in author-focused journals like Heidegger Studies.

But however sizeable the proportion of author-focused work is in relation to total output of general philosophy articles - and I have no evidence on this - that would, after all, only be in line with the discipline's traditional interest in scholarly studies of texts from Plato onwards (as well as in particular problems). A crucial difference between British philosophy of education since the 1960s and general philosophy is that the former was orientated in its heyday towards direct discussion of issues relevant to educational practice rather than towards scholarship largely for its own sake. This is what is to be expected of an area of applied philosophy. The fact that nearly half of JOPE's content is now on particular philosophers with views on education is comparable to a medical ethics journal looking at patient autonomy, euthanasia, brain damage etc as often as not through the lens of a philosopher like Hippocrates, Galen or - on the body's relation to the mind - Descartes or Papineau.

In the 1967-76 period JOPE published just 98 articles, 96 of them about matters relevant to teacher education. With so few appearing every year, nearly all of them were widely discussed and used in courses with teachers. At least a quarter of the 96 were replies to other JOPE articles. This emphasis on debate underlined the message that critical discussion of ideas is central to thinking philosophically about education and added strength to the project of creating a critically reflective teaching force.

Rather than 10 articles a year, at present JOPE typically publishes around 40 . If we add to this the annual tally from other main journals in the subject, the total is over $200 .{ }^{10}$ Very few are replies to other papers. Virtually every academic in the British philosophy of education world in the 60s and 70s was familiar with the arguments in those 10 JOPE pieces per annum (as well as with most of the new books in the field) and used them in teaching teachers. But today it is all but impossible to keep abreast of the subject, especially because 
many of these 200+ articles, as in JOPE's case, appeal to those interested in a particular philosopher or in a specialised subject. All this is in line with the thought that - largely owing to research assessment exercises and the pressure to get published - philosophers of education now have other priorities besides serving the needs of teachers.

But more practical concerns have by no means disappeared. Over $50 \%$ of recent JOPE articles, after all, are not textually orientated. Many articles in recent years have been concerned with living issues in school education. How far these ideas percolate into the world of school teaching and policy-making, rather than being confined to a far smaller circle of academics interested in these areas, is another matter. ${ }^{11}$

A surprisingly large number of recent articles in JOPE have been about education research in universities. Since 1967, 'of the more than fifty papers on educational research, all but three early ones (i.e. over 90\%) were published between 2000 and 2011. Forty-two of the latter were in three Special Issues and one Supplementary Issue between 2001 and 2008. ${ }^{12}$ As Davis and White (2017), from whom these data come, suggest, the burst of interest in this topic may well reflect the compulsory research training for doctoral students introduced in Britain around this time. Just as earlier philosophers of education mostly taught intending or experienced school teachers, so many of their successors now run classes for PhD students in philosophical aspects of educational research. As before, journal material on the subject has soon found its way into course reading lists.

In addition, several philosophers of education working in Britain today have been influential in policy circles, notably Gert Biesta in educational reform in Belgium and the Netherlands, James Conroy in education in Scotland, Andrew Davies in assessment and phonics learning, Richard Pring in 14-19 education and training (he chaired the Nuffield Review of this topic), Christopher Winch in vocational education. David Bridges, who like Pring was a contributor to JOPE in its first slim decade, has recently published on teacher education as well as being prominent in international educational development in both Ethiopia and Kazakhstan. He also co-edited all four JOPE issues on educational research, mentioned above.

With relevance to current developments in education in mind, in 1999 PESGB founded a new series of short policy- and school-related booklets called 'IMPACT'. These have challenged the status quo on such issues as whether foreign languages should be compulsory, performance-related pay, epistemologically-based problems with school examinations, education for patriotism, sex education, a critique of general thinking skills, what schools should be for, character education and education for sustainable development. Not surprisingly, the authors of these pamphlets have been exclusively philosophers of education and general philosophers in the problem-centred tradition mentioned above. Those more at home working on texts of particular philosophers have so far not participated. IMPACT launches have attracted well-known speakers in the political and educational worlds, including, in 2005, a young David Cameron on the point of being chosen to lead the Conservative Party.

One of these IMPACT pamphlets (Orchard and Winch 2015) is specifically on 'What training do teachers need?'. Its answer, enshrined in its sub-title, is 'Why theory is necessary to good teaching'. The booklet advocates greater attention to educational theory not only in ITE, but 
also at MA level in the first two years of teaching, after which one achieves 'full licensure' as a teacher. One of its co-authors, Janet Orchard, has spearheaded several other initiatives on teacher education within PESGB, including residential and other courses for serving teachers on philosophical issues. In an echo of the old Easter School in Philosophy, in October 2017 the University of Birmingham organised a one-day conference on philosophy for teachers. Some PESGB members are also involved, as supporters and as critics, in Philosophy for/with Children, an activity that has recently attracted interest especially from primary schools.

I very much welcome these initiatives on policy issues and teacher education. But at the same time, they bring into relief the change in British philosophy of education since the 1960-80 period. Then, teacher education and the improvement of the educational system were at the heart of the subject. There was no need, as there has been since the millennium, for initiatives like IMPACT and occasional courses and conferences. Today, education policy and teacher education are no longer the main foci of the enterprise. ${ }^{13}$

\section{Conclusion}

The expectation that many philosophers of education had in the 1970s and 1980s that their future lay partly in ITE but much more extensively with teaching and publishing activities for philosophically-minded teachers at CPD level has not been realised. ${ }^{14}$ Is this still a goal worth pursuing? Has the character of the subject changed so much that there is no going back? There are now only odd remnants of what was once a nationwide structure to help teachers critically appraise their work and the wider system. Many teachers, school leaders and senior staff not least, are pressured to attain narrowly-defined standards (Orchard and Winch, ch2). They are often overworked and their meagre CPD is usually specifics-focused. They are expected to take on trust the aim of the National Curriculum as shaped by ministerial preferences - that it 'provides pupils with an introduction to the essential knowledge they need to be educated citizens. It introduces pupils to the best that has been thought and said, and helps engender an appreciation of human creativity and achievement.' Challengeable, telegrammatic messages like this are meant to be their overarching guides - and take us back to the inspirational approach of John Gill and Percy Nunn, but without the religious or scientific surrounds.

The case is as strong as it ever was for a philosophical component in ITE but more especially at CPD level. - Not for all serving teachers, since not all want to explore issues in philosophy of education at some depth. But those who do - those, for instance, who are puzzled about the nature of the learner's mind or what schools' aims should be, or who feel they need the intellectual equipment to assess official policies and fashionable ideas - will find the subject can be as liberating and fulfilling as it was for many forty or fifty years ago.

Given the strength of this case, how if at all might the longstanding aspiration of British philosophy of education be realised? Recent activities in PESGB provide a bridgehead; and JOPE's current policy is to encourage such practical relevance and increase the number of articles it publishes on material relevant to teachers, parents and policymakers. But there also needs to be a change in the wider educational Zeitgeist. Philosophical thinking is unlikely to flourish in the narrow, test-driven, government dominated school system we have today. The stranglehold of testing and examining needs 
to be loosened. The National Curriculum would benefit by removal from ministerial interference. A lighter-touch version could be made the remit of a Curriculum Commission at arms-length from government. This would allow schools themselves to determine far more of what and how they taught. These reforms are independently justifiable apart from their implications for teacher education. ${ }^{15}$ But they also point towards the need for theoryrich CPD tailor-made to the schools' new role, some of it - for those so inclined - of a philosophical nature. ${ }^{16}$

\section{Notes}

1 'In 1839 the English Parliament first disbursed funds for the formal education of teachers.' (Berner 2008: p.1)

${ }^{2}$ Empirical fields of educational theory like comparative education and the sociology, psychology and history of education did not figure in nineteenth-century teacher training, and scientific psychology of education only appeared at the end of this period. None of these areas are what I have called 'philosophical' in the broader sense.

${ }^{3}$ Examples of these continuing debates can be found in Davis, R. and White, P. (eds.) (2017) See especially the Context and Connections for R.S. Peters 'Education and the Educated Man: Some further reflections' and T.H. McLaughlin 'Parental Rights and the Religious Upbringing of Children'.

${ }^{4}$ For an account of the heavily theory-laden PGCE course at the Institute of Education between 1963 and 1973, see Aldrich, R. (2002), pp 170-3.

${ }^{5}$ Use search facility for Student Handbooks / Course Handbooks 1970s, 1980s at http://uclprimo.hosted.exlibrisgroup.com/primo_library/libweb/action/search.do?vid=UCL_VU1\&rese t_config=true

${ }^{6}$ For a participant's experience of these courses in the late 1970s, see Clark, J. A. (2013) 'The Place of Philosophy in the Education of Teachers: Peters revisited' Educational Philosophy and Theory 45:2

7 Some material in this and the preceding two paragraphs is based on personal testimony and records.

8 McClelland, A. and Varma V.P. (1989) Advances in Teacher Education Routledge and Kegan Paul pp. 182-3 https://books.google.co.uk/books?isbn=0415698901

${ }^{9}$ In the most recent available issues over a two-year period of three leading British philosophy journals, the number of article titles mentioning a philosopher range from $9 \%$ in Philosophical Quarterly, to $11 \%$ in Mind, to $18 \%$ in Philosophy. This compares with $48 \%$ in JOPE in 2015-16. As for recent European philosophers, there are none mentioned in these most recent titles in general philosophy journals, compared with the $15 \%$ in JOPE (2012-16). 
${ }^{10}$ There are about 100 from Educational Philosophy and Theory, about 48 from Studies in Philosophy and Education, and about 30 from Ethics and Education.

${ }^{11}$ Some of these are survivors from the pre-1990 era, writing as in the past for an implicit audience of teachers. The difference now is that that audience scarcely exists.

12 See Davis and White (2017) Context and Connections for 'Paul Standish "Data Return: The Sense of the Given in Educational Research"'.

${ }^{13}$ A question worthy of separate investigation is to what extent links between British philosophy of education and teacher education, now sparse for the most part, are strong in the field of religious education. This would not be surprising, given the subject's links with philosophy and moral questions. (GCSE and A level Religious Studies courses, for instance, usually include philosophy and ethics.) Several key positions in PESGB and its publications are held by scholars with a theological background who have written about or taught RE. Many of the currently most active PESGB members teach in universities with a religious foundation. What significance data like these have is uncertain and possibly coincidental, not least because people without religious affiliations or beliefs write about or teach RE, or work in the universities mentioned. There is room for a fine-grained investigation of the place that religious education and religious thinking have in British philosophy of education today. This would partly turn on what is meant by 'religious', so the proposed research could usefully take into account the many recent writings on topics like spirituality, the meaning of life, wonder and contemplation, given their Janus-faced nature between secular and non-secular understandings of them.

${ }^{14}$ Anthony O'Hear, whose 1988 pamphlet called for a cut in educational theory in ITE courses (p26), was not at all so dismissive of in-service provision. He argued that the theoretical study of education 'should be made available to teachers who feel a need for it' but suggested that this was more suitable for experienced teachers than at the ITE stage.

${ }^{15}$ For a detailed case in favour of these suggestions, see Reiss and White (2013), pp 48-65.

${ }^{16}$ I am grateful to Patricia White for her helpful suggestions about this article.

\section{References}

Aldrich, R. (2002) The Institute of Education 1902-2002: a centenary history London: Institute of Education Press

Berner, A. (2008) 'Metaphysics in Educational Theory: educational philosophy and teacher training in England (1839-1944)' University of Oxford D Phil thesis

Davis, R. and White, P. (eds) (2017)

The Journal 1966-2016 Virtual Special Issue of the Journal of Philosophy of Education 
http://onlinelibrary.wiley.com/journal/10.1111/(ISSN)1467-

9752/homepage/the journal 1966-

2016.htm?campaign=dartwol\%7C250231370

Nunn, T.P. (1920) Education: Its Data and First Principles London: Edward Arnold

O'Hear, A. (1988) Who Teaches the Teachers? London: Social Affairs Unit

Orchard, J. and Winch, C. (2015) What training do teachers need? Why theory is necessary for good teaching IMPACT No 22 Oxford: Wiley Blackwell. Available at http://onlinelibrary.wiley.com/doi/10.1111/imp.2015.2015.issue-22/issuetoc

Peters, R.S. (1969) (ed.) Perspectives on Plowden London, Routledge and Kegan Paul

Reiss, M. and White, J. (2013) An Aims-based Curriculum: the significance of human

flourishing for schools London: Institute of Education Press

White, J. (1982) The Aims of Education Restated London, Routledge and Kegan Paul 